\title{
The Performance of Entrepreneurial Ventures with Special Reference to Madurai City
}

Dr.M.Karthikeyan, Associate professor, Department of finance and business analytics,
Kalasalingam University, Tamilnadu. Email: profkarthikeyan01@gmail.com

K.Vidhya, Department of Busimess administration,

Kalasalingam University, Tamilnadu. Email:kkvidhyamba@gmail.com

K.Vijayalakshmi, Research scholar, Department of Busimess administration Kalasalingam University, Tamilnadu. Email: vgsankar@gmail.com

\begin{abstract}
Small business and entrepreneurship has emerged as an important area of research over the past 40 years. Much of this development has been achieved by drawing on and adapting the theoretical frameworks of disciplines from outside. In a developing country like India, Small Scale Entrepreneurship plays a significant role in economic development of the country. These industries, by and large represent a stage in economic transition from traditional to modern technology after globalization. The variation in transitional nature of this process is reflected in the diversity of these industries. Most of the small scale industries use simple skills and machinery. Besides playing economic role in the country, small scale industries, because of their unique economic and organizational characteristics, also play social and political role in local employment creation, balanced resource utilization, income generation and in helping to promote change in a gradual and peaceful manner. The study of entrepreneurship is essential not only to solve the problem of industrial development but also to solve the problems of unemployment, unbalanced areas development, concentration of economic power and diversion of profits from traditional avenues of investment. In this backdrop, the present study attempts to get insights to review, in brief, the evolution of the concept of entrepreneurship, the definition of small scale enterprises and also to study the small scale entrepreneurship in Madurai district.
\end{abstract}

Keywords: Entrepreneurship, Entrepreneur, Small Scale Industry, Madurai District, Economic Power, and Development

\section{Introduction}

The small-scale entrepreneurs undertaking has changed over time. Small enterprises are the engine of growth in many economies around the world, especially in India; it has imperative contribution towards national growth in the new millennium. The small-scale sector entrepreneurs have emerged as a dynamic and vibrant player of the Indian economy in recent years, displaying phenomenal growth in the field of production, employment and dispersed development and overall development. Small-scale Entrepreneurs in India enjoy a distinct position in view of their contribution to the socio-economic development of the country.They contribute a lot to the progress of GDP (Gross Domestic Product) in Indian economy. There are nearly 34 lakhs small-scale entrepreneurs in the country accounting for about $40 \%$ of the gross value of output in the manufacturing sector. In addition, they contribute almost $45 \%$ of the total exports from India. The small-scale entrepreneurs sector has been considered as a powerful instrument for realizing the twin objectives: 'Accelerated Industrial Growth'and creating additional 'Productive Employment Potential', in rural and backward areas.

\section{Meaning and concept of Small Scale Industry}

In most of the developing countries like India, Small Scale Industries (SSI) constitute an important and crucial segment of the industrial sector. They play an important role in employment creation, resource utilisation and income generation and helping to promote changes in a gradual and phased manner. 


\section{Entrepreneurship and Startups}

They have been given an important place in the framework of Indian planning since beginning both for economic and ideological reasons. The reasons are obvious.

The scarcity of capital in India severely limits the number of non-farm jobs that can be created because investment costs per job are high in large and medium industries. An effective development policy has to be attempted to increase the use of labour, relative to capital to the extent that it is economically efficient. Small scale enterprises are generally more labour intensive than larger organizations. As a matter of fact, small scale sector has now emerged as a dynamic and vibrant sector for the Indian economy in recent years. It has attracted so much attention not only from industrial planners and economists but also from sociologists, administrators and politicians.

\section{Scope of the Study}

This study is confined to small-scale industries which are located in Madurai District of Tamil Nadu, India. The objective of this study is to analyze the development of the small-scale entrepreneurs.The study will also be useful for the academicians and policy makers.

\section{Objectives of the Study}

The main objective of the study is to know the smallscale entrepreneurs in Madurai District. In order to achieve the primary objective, the following other objectives are given below.

- To study the growth and performance of smallscale entrepreneurs in Madurai District.

- To identify the factors that motivated the Entrepreneurs to set up small-scale units.

- To analyse the socio-economic background of the small-scale entrepreneurs of Madurai District.

\section{Review of Literature}

Andrew Brimmer [1955 $]^{(1)}$ conducted an intensive and analytical study of the managing agency system on the setting of entrepreneurship in India. In his study, he explains the origin and growth of the system and indicated its contributions to economic development. He argues that the managing agency system of industrial organization was the result of efforts by the British and Indian entrepreneurs to overcome the hardships caused by the lack of capital and business acumen. This system gave more scope for such scarce factors as finance and management but it led to extensive concentration of wealth in a few and malpractices.

In the early fifties Mc Crory [1956] ${ }^{(2)}$ studied small scale firms, 14 in Chopur and 3 in Moradabad towns in Uttar Pradesh with the objective of finding out whether there, were typical patterns of growth in the small machine industries and if so, to isolate, by comparing the case histories of individual enterprise, the common factors that were associated with growth, decline or stagnation. He considered family background in crafts as a necessary source of good industrial entrepreneurs. He analyzed the causes for the high mortality rate among the firms and lack of growth in them. He recommended that an opportunity to grow be given to them through provision of capital.

Berna [1960] ${ }^{(3)}$ conducted an indepth study of 52 medium scale manufacturing units engaged in light engineering production in and around the Madras and Coimbatore cities. His study purport to review the occupational and socio-economic background of the group of entrepreneurs, their origin, the way in which they became entrepreneurs, and the hardships they faced in the establishment and development of their enterprises. This study reveals that $85 \%$ of the enterprises established as small scale unit: were developed over the years into medium scale units. He observed that many entrepreneurs have diversified into production activity and shifting it into new lines of activity, though their performance in technological improvement has not been impressive. Dr. Berna feels that if a certain package of help in techniques of production process and management could be provided to the entrepreneurs, their performance could be considerably improved. 


\section{Entrepreneurship and Startups}

Alexander [1961] $]^{(4)}$ has conducted a study of 354 Greek Industrialists, pertaining to the supply of entrepreneurs and the nature of their policies. He observed that "the reforms of kemal Ataturk inflicted damage to the prestige and status of some groups of Greek people. These groups were well attracted by the lure of large profits and new opportunities". He identifies the following as some of the root causes for the low success rate of Greek entrepreneurs high cost of production, inability to tackle problems effectively, and unsympathetic attitude towards workers, reluctance to share with others ownership and control of enterprise influence of Greek cultural values and lack of proper educational base for their role as managers.

With reference to Indonesia, which had been under the occupation of the Dutch, Higgins[1961 $]^{(5)}$ notes that entrepreneurship developed on the Indonesian Islands where the impact of Dutch destruction has entrepreneurial motives was not deep rooted. While Balians have a group's focused image of change, the Japanese have also focused image of change.

In another study of Indonesian entrepreneurs, Kroef [1962 $]^{(6)}$ considered the entrepreneurs in relation to the middle class of the country. He emphasized that the economic development of the country was impeded by political factors and he did not consider the religious or cultural factors as impediments to the entrepreneurial development in Indonesia.

The UNESCO Research Centre [1962] ${ }^{(7)}$ in its study on a mat industry of Howrah in West Bengal observed that the industrial entrepreneurship sprang up gradually owing to a shift in the entrepreneurs from their traditional occupation to industry. This might have been due to their educational attainment, which stimulated prospective entrepreneurs to come out with a resolution to succeed.

\section{Research Methodology}

Descriptive research is carried out in this article to know thesmall scale entrepreneurs in Madurai district.

\section{Sampling Plan:}

- Type of sampling technique: Convenient sampling

- Sample unit: Small scale entrepreneurs in Madurai district

- Sample size: The sample size is225 respondents.

\section{Sources of Data}

Primary data : Small scale entrepreneurs in Madurai district.

Secondary Data - Journals, Articles, Websites

Data Collection Tool: Structured Questionnaire.

Tools for analysis:

Percentage analysis, ANOVO, Chi-square

\section{Data Analysis And Interpretation}

AGE OF THE RESPONDENTS

An attempt has made to know about the age of the respondents. For the purpose of this study, age has been classified into four categories viz., below 30
(1.Andrew, F. Brimmer, The Settings of Entrepreneurship in India", The Quarterly Journal of Economics, November, 1955, p.553-576.

2. James T. McCrory, Case Studies in Latent Industries Potential: Small Industry in a North Indian Town, Ministry of Commerce and Industry, Government of India, Delhi, 1956.

3. Berna, J.J., Industrial Entrepreneurship in Madras State, Asia Publishing House, Bombay, 1960.

4. Alexander.A.P., Greek Industrialists-An Economic and Social Analysis, Centre of Planning and Economic Research, Athens, 1961.
5. Higgins, Benjamin, Introduction to a Symposium on Entrepreneurship and Labour skills in Indonesian Economic Development, Yale University, South East Asia Studies, NewHavens, Conn.,1961.

6. Kroef.J.M.Van Der, "Entrepreneurs and Middle Class in Indonesia", Economic Development and Cultural Change, Vol.2, p.197-375.1962

7. UNESCO Research Centre, Social Aspects of Small Industries in India: Studies in Hawrah and Bombay, UNESCO Research Centre on Social and Economic Development in Southern Asia, Delhi, 1962) 


\section{Entrepreneurship and Startups}

years, 30 to 40 years, 40 to 50 years and above 50 years. The details are furnished in the table 1.1.

TABLE NO. 1.1

AGE OF THE RESPONDENTS

\begin{tabular}{|l|l|l|l|}
\hline $\begin{array}{l}\text { S. } \\
\text { No. }\end{array}$ & Age & $\begin{array}{l}\text { No. of } \\
\text { Respondents }\end{array}$ & Percentage \\
\hline 1 & Below 30 yrs. & 45 & 20.0 \\
\hline 2 & 30 to 40 yrs. & 89 & 39.6 \\
\hline 3 & 40 to 50 yrs. & 63 & 28.0 \\
\hline 4 & 50 \& above & 28 & 12.4 \\
\hline & Total & $\mathbf{2 2 5}$ & $\mathbf{1 0 0 . 0}$ \\
\hline
\end{tabular}

It is observed from the table 1.1 that 20.0 percent of the respondents belong to the age group of below 30 years, 39.6 percent of the respondents belong to the age group of 30 to 40 years, 28.0 percent of the respondents belong to the age group of 40 to 50 years and 12.4 percent of the respondents belong to the age group of above 50 years. It is found from the analysis that majority (39.6\%) of the respondents belong to the age group of 30 to 40 years.

CHART NO. 1.1

\section{AGE OF THE RESPONDENTS}

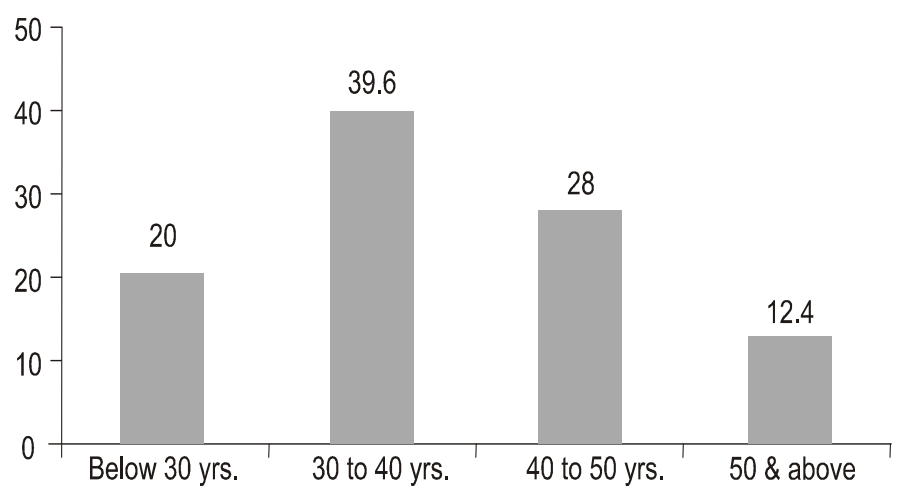

\section{CHI-SQUARE ANALYSIS}

\section{AGE AND LEVEL OF SATISFACTION}

Age is an important factor to determine the success level of the entrepreneurs in small scale industries. For the purpose of this study, age group was studied under four classification viz., below 30 years, 30 to 40 years, 40 to 50 years and above 50 years. The sample consists $45(20.0 \%)$ respondents belonged to below 30 years age group, 89 (39.6\%) respondents were 30 to 40 years age group, 63 (28.0\%) respondents were $40-50$ years age group. On the other hand $28(12.4 \%)$ respondents belonged to above 50 years age group. The distribution of sample respondents according to the age of the respondents and their level of satisfaction towards small scale industries are shown in the Table1.2.

TABLE NO. 1.2

AGE AND LEVEL OF SATISFACTION

\begin{tabular}{|l|l|l|l|l|l|l|l|}
\hline S. & Age & $\begin{array}{l}\text { No.of } \\
\text { No. }\end{array}$ & & Respo & & Ave & \multicolumn{2}{|l|}{ Range } & S.D \\
\cline { 6 - 8 } & & rage & & Min & Max & \\
\hline 1 & Below 30 yrs. & 45 & 20.0 & 50.2 & 45 & 59 & 3.0 \\
\hline 2 & 30 to 40 yrs. & 89 & 39.6 & 49.7 & 42 & 59 & 3.1 \\
\hline 3 & 40 to 50 yrs. & 63 & 28.0 & 49.5 & 42 & 55 & 2.8 \\
\hline 4 & 50 \& above & 28 & 12.4 & 47.9 & 29 & 54 & 4.4 \\
\hline & Total & 225 & 100.0 & & & & \\
\hline
\end{tabular}

It could be observed from the above table that the level of satisfaction towards the small scale industries perceived by the respondents belong to the age group of below 30 years ranged between 45 and 59 with an average of 50.2. The level of satisfaction towards the respondents of small scale industries perceived by the respondents with the age group of 30-40 years ranged between 42 and 59 with an average of 49.7 . On the other hand, the level of satisfaction towards of small scale industries perceived by the respondents in the age group of 40-50 years ranged between 42 and 55 with an average of 49.5 . Finally, the respondents with the age group of above 50 years revealed their level of satisfaction towards the small scale industries ranged between 29 and 54 with an average of 47.9. From the analysis, it is inferred that the maximum level of satisfaction towards the small scale industries perceived by the respondents in the age group of below 30 years.

With a view to find the degree of association between age of the respondents and the level of satisfaction 


\section{Entrepreneurship and Startups}

towards small scale industries, a two-way table was prepared and it is exhibited in the Table 1.3.

TABLE NO. 1. 3

AGE AND LEVEL OF SATISFACTION (TWO-WAY TABLE)

\begin{tabular}{|c|l|l|l|l|l|}
\hline \multirow{2}{*}{$\begin{array}{l}\text { S. } \\
\text { No. }\end{array}$} & \multirow{2}{*}{ Age } & \multicolumn{3}{|c|}{ Level of satisfaction } & \multirow{2}{*}{ Total } \\
\cline { 3 - 5 } & & Low & Medium & High & \\
\hline 1 & Below 30 yrs. & $\begin{array}{l}9 \\
(20.0)\end{array}$ & $\begin{array}{l}15 \\
(33.3)\end{array}$ & $\begin{array}{l}21 \\
(46.7)\end{array}$ & 45 \\
\hline 2 & 30 to 40 yrs. & $\begin{array}{l}25 \\
(28.1)\end{array}$ & $\begin{array}{l}28 \\
(31.5)\end{array}$ & $\begin{array}{l}36 \\
(40.4)\end{array}$ & 89 \\
\hline 3 & 40 to 50 yrs. & $\begin{array}{l}5 \\
(7.9)\end{array}$ & $\begin{array}{l}36 \\
(57.1)\end{array}$ & $\begin{array}{l}22 \\
(34.9)\end{array}$ & 63 \\
\hline 4 & 50 \& above & $\begin{array}{l}8 \\
(28.6)\end{array}$ & $\begin{array}{l}13 \\
(46.4)\end{array}$ & $\begin{array}{l}7 \\
(25.0)\end{array}$ & 28 \\
\hline & Total & $\mathbf{4 7}$ & $\mathbf{9 2}$ & $\mathbf{8 6}$ & $\mathbf{2 2 5}$ \\
\hline
\end{tabular}

It could be identified from the above table that the percentage of high level of satisfaction towards the small scale industries was the highest $(46.7 \%)$ among the respondents of below 30 years age category and the same was the lowest $(25.0 \%)$ among the respondents of above 50 years age category.

The percentage of medium level of satisfaction towards the small scale industries was the highest (57.1\%) among the respondents of 40 to 50 years age group and the same was the lowest (31.5\%) among the respondents of 30 to 40 years of age category. The percentage of low level of satisfaction towards the small scale industries was the highest (28.6\%) among the respondents of above 50 years and the same was the lowest (7.9\%) among the respondents of 40 to 50 years.

In order to find the relationship between the age of the respondents and their level of satisfaction towards the small scale industries, the following null hypothesis was framed and tested with the help of Chi-square test and the result is shown in the following table.

$\mathrm{HO}$ :There is no significant relationship between age and level of satisfaction towards the small scale industries.
$\mathrm{H} 1$ :There is a significant relationship between age and level of satisfaction towards the small scale industries.

TABLE NO. 1.4

AGE AND LEVEL OF SATISFACTION

(CHI-SQUARE TEST)

\begin{tabular}{|l|l|l|l|l|}
\hline Factor & $\begin{array}{l}\text { Calculated } \\
\chi^{2} \mathbf{2} \text { Value }\end{array}$ & $\begin{array}{l}\text { Table } \\
\text { Value }\end{array}$ & D.F & Remarks \\
\hline Age & 17.336 & 12.592 & 6 & $\begin{array}{l}\text { Significant at } \\
5 \% \text { level }\end{array}$ \\
\hline
\end{tabular}

It is divulged from the table 1.4 that the calculated chi-square value is greater than the table value and the result is not significant. Hence the hypothesis, "age of the respondents and the level of satisfaction towards the small scale industries are not associated" does not hold good. From the analysis, it is found that there is a close relationship between the age of the respondents and their level of satisfaction towards the small scale industries.

\section{ANOVA ANALYSIS}

\section{PRODUCTION ISSUES}

The opinion of the selected sample respondents towards production issues in their small scale industries discussed in the Table 1.5.

TABLE NO. 1.5

SOCIO-ECONOMIC PROFILE AND PRODUCTION ISSUES

\begin{tabular}{|l|l|c|c|c|}
\hline $\begin{array}{l}\text { S. } \\
\text { No. }\end{array}$ & $\begin{array}{l}\text { Socio-economic } \\
\text { Profile }\end{array}$ & $\begin{array}{c}\text { No. of } \\
\text { Respondents }\end{array}$ & Percentage & Mean \\
\hline & Age & \multicolumn{4}{|l|}{} \\
\hline 1. & Below 30 yrs. & 45 & 20.0 & 33.0 \\
\hline 2. & 30 to 40 yrs. & 89 & 39.6 & 33.3 \\
\hline 3. & 41 to 50 yrs. & 63 & 28.0 & 32.6 \\
\hline 4. & Above 50 yrs. & 28 & 12.4 & 32.0 \\
\hline & Gender & 188 & 83.6 & 32.8 \\
\hline 1. & Male & 37 & 16.4 & 33.0 \\
\hline 2. & Female & \multicolumn{5}{|l}{} \\
\hline
\end{tabular}




\section{Entrepreneurship and Startups}

\begin{tabular}{|c|l|c|c|c|}
\hline \multicolumn{4}{|l|}{ Educational Qualification } \\
\hline 1. & School level & 30 & 13.3 & 32.9 \\
\hline 2. & Graduate & 110 & 48.9 & 33.0 \\
\hline 3. & Post Graduate & 27 & 12.0 & 32.1 \\
\hline 4. & Others & 58 & 25.8 & 33.0 \\
\hline & Technical Qualification & \multicolumn{3}{l|}{} \\
\hline 1. & ITI level & 26 & 11.6 & 33.0 \\
\hline 2. & Diploma & 32 & 14.2 & 32.7 \\
\hline 3. & Engineering & 40 & 17.8 & 32.2 \\
\hline 4. & Others & 127 & 56.4 & 32.3 \\
\hline & Generation of being entrepreneur & \\
\hline 1. & First generation & 116 & 51.6 & 33.0 \\
\hline 2. & Second generation & 65 & 28.9 & 32.6 \\
\hline 3. & Third generation & 23 & 10.2 & 32.8 \\
\hline 4. & Fourth generation & 21 & 9.3 & 32.8 \\
\hline \hline
\end{tabular}

It could be observed from the table 1.5 that 30 to 40 years having maximum level of production issues followed by female respondents who are having maximum level of production issues. It is followed by graduates and other educational qualified respondents who are having the highest level of production issues. The ITI level respondents are having maximum level of production issues. The first generation entrepreneurs are having maximum level of production issues.

Hypothesis : There is no significant difference between socio-economic profile of the entrepreneurs and production issues

\section{Findings \& Suggestions}

The main findings of the study are as follows:

- It is found that majority (39.6\%) of the respondents belong to the age group of 30 to 40 years.

- It is noted that majority $(83.6 \%)$ of the respondents are male.

- It is inferred that the maximum level of satisfaction towards the small scale industries perceived by the respondents in the age group of below 30 years. It is accepted by the Chisquared test at 5 percent level of significance association.

- It could be observed from the table that the factors like age, technical qualification and generation are having significant difference with the production issues.

Entrepreneurs could be trained on technical knowhow and can gain much proficiency in their work related areas like how to access capital within the time frame, Where to market their products and thereby creating assets and choosing the right form of enterprise and the nature of industry which will help them to sustain in the long run in the competitive environment.

\section{Conclusion}

In this article the researcher has attempted to provide an insight into the life of small scale entrepreneurs in Madurai district. It is concluded that the technical persons in the factory may be provided with the latest training in the right place and try to implement the advanced technology to increase the productivity. This will help the entrepreneurs to be more successful in their business and also help the entrepreneurs to face the competition in the international level very easily.

\section{References}

1 Hisrich, PhD, Robert D., Michael P. Peters, PhD and Dean A. Shepherd, PhD. Entrepreneurship. 6 ed. New York: McGraw-Hill Irwin, 2005.

2 Schumpeter, J A. 1934. The Theory of Economic Development: An Inquiry into Profits, Capital,Credit, Interest, and the Business Cycle. Cambridge, MA.: Harvard University Press.

3 Anyanwu C. M. (2001): Financing and Promoting Small Scale Industries, Concepts, Issues and Prospects. Bullion Publication of CBN, 25(3): 12 $-15$.

4 Berkeley, Rural small scale Industry in the people's Republic of China. 1967, University of California press. 


\section{Entrepreneurship and Startups}

5 Ashokkumarsingh. 1970, "Problems and prospects of small scale industries in Bihar: A critical study" PhD, Theis, Bihar University.

6 Nisae Ahmad. 1970, "Problems and management of small scale and cottage Industries", New Delhi. Deep and Deep publication.

7 Gadgil, D.R., The Industrial Evolution of India in Recent Times: 1860-1939, Oxford University Press.

8 Berna, J.J., Industrial Entrepreneurship in Madras State, Asia Publishing House, Bombay, 1960.

9 Alexander.A.P., Greek Industrialists-An Economic and Social Analysis, Centre of Planning and Economic Research, Athens,1961.

10 Higgins, Benjamin, Introduction to a Symposium on Entrepreneurship and Labour skills in Indonesian Economic Development, Yale University, South East Asia Studies, NewHavens,Conn.,1961.
11 UNESCO Research Centre, Social aspects of Small Industries in India: Studies in Hawrah and Bombay, UNESCO Research Centre on Social and Economic Development in Southern Asia, Delhi, 1962.

12 Yousif. A.Sajigh, Entrepreneurs of Lebanon: The Role of Business Leader in Developing Economy, Harvard University Press, Cambridge, 1962.

13 Bert.F.Hoselitz,. The Entrepreneurship Element in Economic Development, International Hand Book of Management, McGraw Hill, NewYork, 1965.

14 John, J.Carroll, The Philippine Manufacturing Entrepreneur: Agent and Product of Change, Corroll University Press ITHACO, 1965.

15 Kilby Peter, Industrialization in an Open Economy, Nigeria, University Press, Cambridge. 1969. 